\title{
MIGRATION IN STATISTICS INDEXES’ TERMS. ROMANIA STUDY CASE
}

https://doi.org/10.47743/jopafl-2021-19-02

\author{
Tatiana-Camelia DOGARU (CRUCEANU) \\ National University of Political Science and Public Administration, Faculty of Public \\ Administration \\ Bucharest, Romania \\ dogaru_tatiana@yahoo.com
}

\begin{abstract}
Complex political, economic, natural and social events shaping the migration phenomenon in all Europe and abroad. Besides, globalisation and Europeanization have resulted in a significant increase in migration flows. Thus, migration become a complex and multi-criteria phenomena with different meanings and estimation methods according to different research objectives. These particularities create an additional pressure on policymakers' shoulders who need a better understanding of the variation of time-series database. Although, have been developed several databases and indices, at the time being there are difficulties regarding the measuring and conceptualization of migration, particularly the return migration within and cross-national framework. This paper discusses these challenges and the methodological limits on migration policy indexes for comparative analysis and learning lessons.
\end{abstract}

Keywords: migration policies, cross-national studies, migration indicators

\section{Introduction}

Governments adopt a wide variety of approaches for regulating migration and over the last decades, there have been increasing efforts to measure the impact of migration policies and to compile figures from migration policy databases. Nowadays, migration is an integral part of the 2030 Agenda for Sustainable Development and a cross-cutting policy theme which drawn the attention of both scholars and policymakers. More than half of its goals are directly related to migration issue. In this sense, the goal purposed to „facilitate orderly, safe, regular and responsible migration and mobility of people, including through the implementation of planned and well-managed migration policies” is the most explicit migration-related target of the 2030 Agenda. Also, migration data need to become a sine quo non condition for policy-making and systematically analysis, and have increased as a results of governmental intention to measure and compare data from migration policy to monitor their progress and learning lessons. Moreover, few years ago, migration and refugees issues brought together 193 UN Member states to set common actions in this field. However, although the interest in measuring migration policies increased and several databases occurred, there is still a lack of data and an IOM's study (2018) concluded that there are fewer data on the following migration topics: irregular migration, migrant health, impact of migration policies, recruitment costs, return migration, smuggling, migrant integration, missing migrants and migration flows, and more data on students, human trafficking, remittances, migrant stocks and ratification of international conventions. Therefore, however there is a context of global migration governance, when we turn to data it can be note few key shortcomings including lack of availability, comparability and 
frequencies of data. So, although a large number of studies have already been published, several challenges are yet to be overcome, especially when policy transfer and learning lesson are discussed.

\section{Research design}

From the need to compare different governmental interventions across countries and over time more projects and initiatives have been conducted to create a common framework for coding and comparing migration policies. Seeing there are different approaches, operationalization and concepts, at the time being there are various databases that give access to policy makers to data which are essentially in the context of policy transfer and learning lessons. Therefore, after a long period in which analyses focused on single or small cases have predominated in the migration specialized literature, an increasing number of studies started to set their goals on comparing relatively large range of cases and building policy indexes.

Based on the diversity of migration databases and their effectiveness to support large-N study cases from comparative perspective this paper use mapping approach. The main goal is to analyse several migration policy indexes, explain their methodologies and usefulness for comparative studies because at the moment there are no systematic approach for analysing and comparing migration policies, especially due to the different perspectives of countries on public intervention and, of course, because of various objectives of researchers on this topic. In this context, classifying, monitoring and comparing migration policies from a cross-nationally perspective become a challenge. The research questions addressed here are: "What databases are available for analysing the migration policies?" "What kind of policies are analysed and which countries are in?" "Can the data be used in comparative view?”

The research objectives consist of:

- Providing a systematically framework on several migration indexes;

- Detecting gaps and best practices in the methodologies;

- Analysing their potential for policy transfer.

Traditional, the statistical methods have the greater influence among the policymakers, but increasingly the complexity of the policy problem shift the view to new research methods, such as comparative method. Suitable for both quantitative and qualitative methodologies and with a large-scale of applicability, the comparative method is applied in cross-cultural and cross-national context, in different policy fields, namely education, health, welfare, as well migration (Dogaru (Cruceanu), T-C., 2019). From a broader perspective, the comparative method is considered a continuous approach, therefore sometimes the scholars refer to it in terms of "constant comparative method". In this sense, it can be outlined the Jupp’ view (2006), which underlines different ways for using comparison, namely documents or content analysis, historical analysis (comparison of time periods) and, statistics analysis.

Of, course we refer here to external migration phenomenon and use a statisticaldescriptive perspective for discussing a non-exhaustive list of the comprehensive databases/indexes. As it is known, based on the approaches used to analyse the migration policies, the specialized literature divides indexes into two main categories: comprehensive and sectorial (EC-JRC, 2018). From the first branch can be find: DEMIG, Global Migration 
Barometer, ICI, IMPALA, IMPIC, MGI, IMPEX and Ortega and Peri, while from the second branch are: CERNA, Openness Index, Deterrence Index and Asylum policy Index.

\section{Migration Policies In Indexes: A Short Overview}

Although modern migration can be caused by various factors, such as: wars, political conflicts, natural disasters, most of them are determined by economic considerations framed through migration policies and other inter-sectorial policies. The variety of migration patterns - permanent migration, temporary migration, repeat migration, seasonal migration, and circular migration and the challenges stemming from the availability and reliability of different data sources make international migration "the most difficult of demographic phenomena to define and measure correctly" (World Bank, 2018: 5). The effective impact of migration should be assessed empirically to facilitate a well-informed governmental intervention. In general, the statistical systems from origin countries have different methodologies for monitoring this phenomenon, so there is a need to compile data from various international databases, but in this case appear the risk of incomparability.

At European Union level the main source of statistics data on international migration is Eurostat. This is complemented by others different databases from international or domestic level. One of the well-known migration policy index is Determinants of International Migration (DEMIG). DEMIG index is a result of DEMIG project and consists of (DEMIG 2015a, 2015b, 2015c):

- DEMIG C2C which covers bilateral migration flow data for 34 countries over the 1946-2011 period and includes data for inflows, outflows and net flows.

- DEMIG TOTAL which reports immigration, emigration and net migration flows for up to 161 countries covering various periods of time from the early 1800s to 2011, disaggregating total flows of citizens and foreigners whenever possible.

- DEMIG VISA which captures both entry visa and exit permit requirements, based on data reported in the Travel Information Manuals published monthly by the International Air Transport Association (IATA).

- DEMIG POLICY which tracks 6505 migration policy changes (both immigration and emigration) in 45 countries, most of them enacted in the 1945-2013 period.

According to de Haas et al. (2015), DEMIG POLICY tracks policy changes occurring in a specific country and year, so its main objective is focused not on policy per se, but on policy changes. Starting from Mayda and Patel (2004) and Hatton (2009) databases, DEMIG POLICY appeals to two concepts, namely policy change and policy restrictiveness and use a 4-point scale to evaluate the policy changes: (1) fine-tuning measures; (2) minor change; (3) mid-level change and (4) major change.

In this index, the migration policies are defined as "rules (i.e., laws, regulations, and measures) that national states define and [enact] with the objective of affecting the volume, origin, direction, and internal composition of [...] migration flows" (de Haas et al. 2015: 3-4). It is worth to note that in that conceptualisation the EU regulations is not take it into account, but only the national transposition of that. So, DEMIG POLICY is focused on the legal aspects of migration policies - policies on paper, not on policy discourses and the implementation of policies. Policy strategies, parliamentary debates and action plans 
are used as contextual evidence of policy-making processes, but they are not coded as migration policy.

Through the main advantages of DEMIG POLICY index can be mentioned the policy changes disaggregation into their different measures, identifying and coding the migrant group targeted by each policy measure and the fact that it tracks both entry and exit policies for all countries included in the database. Regarding the variables and codes a synthetic view is find in the below table.

Table 1. Variables in DEMIG POLICY index

\begin{tabular}{|c|c|c|c|c|}
\hline Policy area & Policy tool & $\begin{array}{l}\text { Migrant category } \\
\text { (target group) }\end{array}$ & $\begin{array}{l}\text { Migrant } \\
\text { origin (target } \\
\text { origin) }\end{array}$ & $\begin{array}{l}\text { Change in } \\
\text { restrictiveness }\end{array}$ \\
\hline $\begin{array}{l}\text { Border and } \\
\text { land control }\end{array}$ & $\begin{array}{l}\text { Surveillance } \\
\text { technology/control } \\
\text { powers }\end{array}$ & All & All & Less restrictive \\
\hline $\begin{array}{l}\text { Legal entry } \\
\text { and stay }\end{array}$ & Identification documents & All migrants & $\begin{array}{l}\text { All foreign } \\
\text { nationalities }\end{array}$ & No change \\
\hline Integration & Detention & All migrants workers & EU citizens & More restrictive \\
\hline \multirow[t]{15}{*}{ Exit } & Carrier liabilities & Low-skilled workers & Citizens & \multirow{15}{*}{$\begin{array}{ll}\text { Change } & \text { in } \\
\text { restrictiveness } & \\
\text { cannot } & \text { be } \\
\text { assessed } & \end{array}$} \\
\hline & Employer liabilities & $\begin{array}{l}\text { Skilled/high-skilled } \\
\text { workers }\end{array}$ & \multirow[t]{14}{*}{$\begin{array}{l}\text { Specific } \\
\text { nationalities }\end{array}$} & \\
\hline & Other sanctions & Family members & & \\
\hline & Travel visa/permit & $\begin{array}{l}\text { Family members of } \\
\text { high-skilled workers, } \\
\text { investors or students }\end{array}$ & & \\
\hline & Work visa/permit & $\begin{array}{l}\text { Family members of } \\
\text { irregular migrants or } \\
\text { refugees, asylum } \\
\text { seekers and other } \\
\text { vulnerable people }\end{array}$ & & \\
\hline & Entry visa/stay permit & International students & & \\
\hline & Points-based system & $\begin{array}{l}\text { Investors, } \\
\text { entrepreneurs } \\
\text { business people }\end{array}$ & & \\
\hline & Quota/target & Irregular migrants & & \\
\hline & Regularisation & $\begin{array}{l}\text { Refugees, asylum } \\
\text { seekers and other } \\
\text { vulnerable people }\end{array}$ & & \\
\hline & Entry ban & Diaspora & & \\
\hline & $\begin{array}{l}\text { Recruitment/assisted } \\
\text { migration programmes }\end{array}$ & \multirow[t]{5}{*}{ Specific categories } & & \\
\hline & $\begin{array}{l}\text { Resettlement } \\
\text { programmes }\end{array}$ & & & \\
\hline & $\begin{array}{l}\text { Free mobility } \\
\text { rights/agreements }\end{array}$ & & & \\
\hline & $\begin{array}{l}\text { Language, housing and } \\
\text { cultural } \\
\text { programmes }\end{array}$ & & & \\
\hline & $\begin{array}{l}\text { Access to social benefits } \\
\text { and socio-economic } \\
\text { rights }\end{array}$ & & & \\
\hline
\end{tabular}




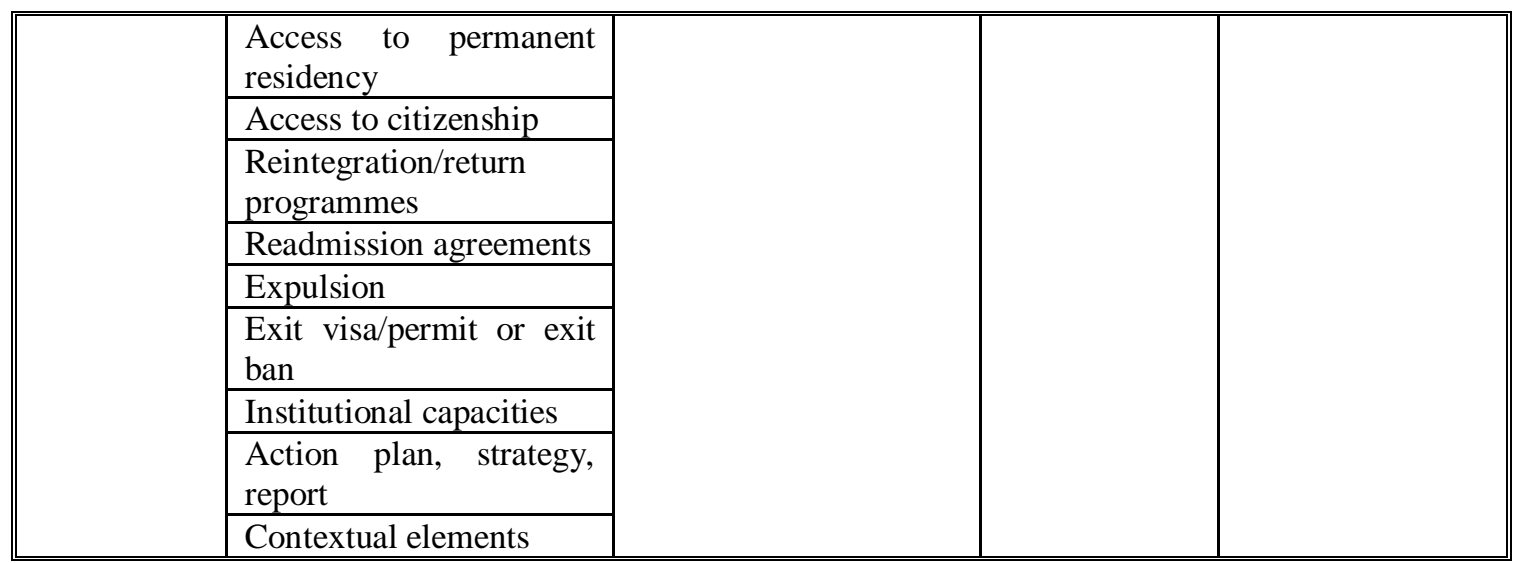

Source: Author based on DEMIG POLICY database, 2004, www.migrationdeterminants.eu

Another representative index is International Migration Policy and Law Analysis (IMPALA). IMPALA is project on comparative immigration policy, aiming to develop "indicators for the overarching concept of restrictiveness/openness" (Gest et al. 2014: 267). As basic unit, IMPALA index uses the entry track meaning a "specific way of entering the country" (Beine et al. 2016: 834) and covers six major areas of migration policy depicted in the below table.

Table 2. Variables in IMPALA index

\begin{tabular}{|c|c|c|c|c|c|}
\hline $\begin{array}{l}\text { Economic } \\
\text { migration }\end{array}$ & $\begin{array}{l}\text { Family } \\
\text { reunification }\end{array}$ & $\begin{array}{l}\text { Student } \\
\text { migration }\end{array}$ & $\begin{array}{l}\text { Humanitarian } \\
\text { migration }\end{array}$ & Naturalization & $\begin{array}{l}\text { Irregular } \\
\text { migration }\end{array}$ \\
\hline $\begin{array}{l}\text { Regulations } \\
\text { for workers }\end{array}$ & $\begin{array}{l}\text { Regulations } \\
\text { for partners }\end{array}$ & $\begin{array}{l}\text { Regulations } \\
\text { for } \\
\text { university }\end{array}$ & $\begin{array}{l}\text { Regulations for } \\
\text { asylum seekers }\end{array}$ & \multirow{5}{*}{$\begin{array}{l}\text { Modes of } \\
\text { acquisition and } \\
\text { loss of } \\
\text { citizenship }\end{array}$} & \multirow{5}{*}{$\begin{array}{l}\text { Regulations for } \\
\text { immigrants } \\
\text { entering a } \\
\text { country without } \\
\text { authorization } \\
\text { and those who } \\
\text { qualify for } \\
\text { removability or } \\
\text { exclusion }\end{array}$} \\
\hline $\begin{array}{l}\text { Regulations } \\
\text { for investors }\end{array}$ & $\begin{array}{l}\text { Regulations } \\
\text { children }\end{array}$ & $\begin{array}{l}\text { Regulations } \\
\text { for school }\end{array}$ & $\begin{array}{l}\text { Regulations for } \\
\text { refugees }\end{array}$ & & \\
\hline \multirow[t]{3}{*}{$\begin{array}{l}\text { Regulations } \\
\text { for } \\
\text { entrepreneurs }\end{array}$} & \multirow{3}{*}{$\begin{array}{l}\text { Regulations } \\
\text { parents and } \\
\text { extended } \\
\text { family } \\
\text { members }\end{array}$} & \multirow{3}{*}{$\begin{array}{l}\text { Regulations } \\
\text { vocational } \\
\text { and } \\
\text { language } \\
\text { students }\end{array}$} & $\begin{array}{ll}\text { Regulations for } \\
\text { subsidiary } & \\
\text { protection } & \\
\end{array}$ & & \\
\hline & & & $\begin{array}{ll}\text { Regulations for } \\
\text { temporary }\end{array}$ & & \\
\hline & & & $\begin{array}{l}\text { Regulations for } \\
\text { residence permits } \\
\text { for personal } \\
\text { reasons (such as } \\
\text { domestic } \\
\text { violence), } \\
\text { medical reasons } \\
\text { and for victims of } \\
\text { human trafficking }\end{array}$ & & \\
\hline
\end{tabular}

Source: Author based on Gest et al., 2014

Regarding sources, "coding is based on referenced and cited acts of parliament and other legal documents” (Gest et al. 2014: 269). The IMPALA focus is on admission policies and coding the laws and regulations from each countries using a common standardized list of questions on an annual basis. The core of this dataset is represented by 
the formal immigration law and regulations. Regarding the countries, according to IMPALA methodologies the index encompasses most economies in the OECD, except those with negative net immigration (i.e. net emigration), nowadays being coded nine countries. So, IMPALA index is supposed to cover 26 countries and additional European Union that is analysed as a particular case, separated to the domestic regulations of members states (Gest et al. 2014). Despite DEMIG, IMPALA codes policies per se. About IMPALA index, it is important to note that at the time writing the data are not publicly available, and the time covered is 1999-2008. A main advantage of this index is the data for labour, both low-skilled and highly-skilled and the correlations with the Rush (2011) measure of restrictiveness.

The Migrant Integration Policy Index (MIPEX) is an index mainly focuses on public policies' measures to integrate migrants. It analyses 8 policies areas of integration and covers 52 countries. According to specialised literature (EC-JRC, 2018), MIPEX is identified as "the most reliable, complete and cited index on integration policies". For this index there are yearly updates and it covers 2007-2019 period. The MIPEX measures national policies on 1-3 scale for equal treatment. In doing so, MIPEX follows a common strand in the literature which differentiates policies along the liberal/restrictive divide (e.g. IMPALA, DEMIG), but with a somewhat more normative stance (EC-JRC, 2018). Thus, through this methodology what is measured is not policies in individual countries, but a country's record related to a definite benchmark.

Table 3. Variables in MIPEX index

\begin{tabular}{|c|c|c|}
\hline Policy areas & $\begin{array}{l}\begin{array}{l}\text { Dimensions of integration } \\
\text { policy }\end{array} \\
\end{array}$ & $\begin{array}{l}\text { Overall approach to integration } \\
\text { (Country's profile) }\end{array}$ \\
\hline market & Basic rights & Comprehensive integration - top ten \\
\hline Education of children & Equal opportunities & Comprehensive integration - Slightly favourable \\
\hline Political participation & \multirow[t]{8}{*}{ Secure future } & Temporary integration - Halfway favourable \\
\hline Family reunion & & Equality on paper - Halfway favourable \\
\hline Access to nationality & & Comprehensive integration - Halfway favourable \\
\hline Health & & Temporary integration - Halfway unfavourable \\
\hline Permanent residence & & $\begin{array}{l}\text { Immigration without integration - Halfway } \\
\text { unfavourable }\end{array}$ \\
\hline \multirow[t]{3}{*}{ Anti-discrimination } & & Equality on paper - Halfway unfavourable \\
\hline & & Equality on paper - Slightly unfavourable \\
\hline & & $\begin{array}{l}\text { Immigration without integration - Most } \\
\text { unfavourable }\end{array}$ \\
\hline
\end{tabular}

Source: Author based on MIPEX. 2020

Global Migration Barometer is another migration index, it covers 61 countries and analyse the main migration policies from three dimensions: attractiveness for migrants, accessibility for migrants and need for migrants. Its methodology has been developed by the Economist Intelligence Unit and under this and with input from Western Union and independent panels of migration experts it collect data. The work definition of this index is the United Nations' definition for long-term international migrant “a person who moves to a country other than that of his or her usual residence for a period of at least a year (12 
months), so that the country of destination effectively becomes his or her new country of usual residence. From the perspective of the country of departure, the person will be a longterm emigrant and from that of the country of arrival the person will be a long-term immigrant" (EIU, 2008). For generating the index are used indicators that reflect the standard of living and economic development of a country, legislative policy and attitudes towards migration, and demographics and social welfare commitments.

Table 4. Variables in Global Migration Barometer index

\begin{tabular}{|c|c|}
\hline Policy dimensions & Indicators \\
\hline \multirow[t]{14}{*}{ Attractiveness to migrants } & Nominal GDP \\
\hline & Nominal GDP per head at PPP \\
\hline & Historic/commercial links \\
\hline & Regional integration \\
\hline & Quality of healthcare \\
\hline & Quality of education \\
\hline & Meritocratic remuneration \\
\hline & Foreign direct investment \\
\hline & Ability/ease of remitting money \\
\hline & Access to financial services \\
\hline & Access to capital \\
\hline & Ease of starting a business \\
\hline & Civil liberties \\
\hline & Social unrest \\
\hline \multirow[t]{8}{*}{ Accessibility for migrants } & Government policy towards migration \\
\hline & Ease of hiring foreign nationals \\
\hline & Licencing requirement for migrants \\
\hline & Ease of family reunification \\
\hline & Programmes to integrate migrants \\
\hline & Openness of host country culture to migrants \\
\hline & Power of trade unions \\
\hline & De jure or de facto discrimination \\
\hline \multirow[t]{10}{*}{ Need for migrants } & Old age dependency ratio \\
\hline & Natural increase \\
\hline & Employment ratio \\
\hline & Rigidity of employment \\
\hline & Labour productivity \\
\hline & Unfunded pension and healthcare liabilities \\
\hline & Public spending on pensions \\
\hline & Unemployment benefits \\
\hline & Internal labour mobility \\
\hline & Labour force \\
\hline
\end{tabular}

Source: Economist Intelligence Unit 2008 
As it can be seen, the most existing data, with few exceptions started to gathering, coding and creating indexes just over a decade ago and cover different periods of time and countries, mostly Western European and traditional settler countries. Unfortunately, for the majority of them there are no updates and the records stop five or even more years ago. A closer look at the existing migration policy indexes reveals a large scale of indicators which cover various aspects of migration policy and different understandings and operationalization of concepts (e.g. emigrants, temporary and permanent migration and immigration, immigration policy, integration policy so on).

Another element that it is important to keep in mind is that some data on migration have as unit of analysis the policy per as while others focus on change in policy. Also, another problem of using figures from different indexes consist of some indexes cover specific aspects of migration policies, such as labour migration, asylum, migrants' rights, and others have a broad perspective. Of course, all of these and more other aspects put certain limitations for comparative studies on migration policy and sometimes datasets are not usefulness for other researchers or policy-makers. Nevertheless, among the existing data there are ones, such as DEMIG, IMPALA, IMPIC which try to be more comprehensive, but these projects also have certain limits, namely publicly availability, updates, countries covered.

Thus, in this context, the scholars who aim to study the migration policies from comparative perspective need to appeal to national sources or international ones and to build their own indices for the research questions they are interesting in answering or to initiate a joint collaborative database based on a common methodology.

\section{A glance on MIGRATION statistics for Romania: Study case}

Nowadays, all countries are simultaneously countries of destination, origin and transit for migrants. It is also the case of Romania, which between 1990 and 1993 was a large compensation movement, constituted mainly of citizens of German origin, who couldn't leave before 1989. This was followed by a decline in migration until the early 2000s. Moreover, the fallen of Romania' population from 22.4 million in 2000 to 19.4 million in 2019 and integration in the European Union, especially the right set by art. 45 of the Treaty on the Functioning of the European Union regarding the free movement of workers amplified the migration issue in Romania and facilitated the label of emigration country for Romania.

In this context, the evidence-based policy and monitoring the migration flows and stocks become key aspects of policy-making. The Romanian National Institute of Statistics (NIS) estimates data on international migration based on its own methodology, developed and approved by the Methodological Approval Committee, in accordance with the requirements of the relevant EU regulations. For example, to be defined as a migrant, the methodologies use different cumulative or not criteria, and NIS has an integrative approach. A view on this is reflected into the below table.

Table 5. NIS criteria for defining the migration

\begin{tabular}{|l|l|l|l|l||}
\hline \hline Criteria & Eurostat & ONU & OECD & NIS \\
\hline Citizenship & $\sqrt{ }$ & $\sqrt{ }$ & $\sqrt{ }$ & $\sqrt{ }$ \\
\hline Country of origin & $\sqrt{ }$ & $\sqrt{ }$ & $\sqrt{ }$ & $\sqrt{ }$ \\
\hline
\end{tabular}




\begin{tabular}{|l|l|l|l|l||}
\hline Time limit & $\sqrt{ }$ & - & - & $\sqrt{ }$ \\
\hline Residence & $\sqrt{ }$ & - & - & $\sqrt{ }$ \\
\hline
\end{tabular}

Source: author based on specialised studies

It is important to remark that, in this context, data for migration phenomenon are correlated to European regulations on international migration. In this sense, according to NIS' methodology the permanent emigration is "the action by which one person ceases to have his or her permanent residence in Romania and establishes his or her permanent residence on the territory of another country", and the temporary emigration means "the action by which a person who had previously been usually resident in the territory of Romania, ceases to have his/her usual residence in Romania for a period that is, or is expected to be, of at least 12 months" (NIS, 2020). Based on figures from NIS, the figures below depict the changes into permanent and temporary emigration in Romania in the last years.

Fig. 1. Changes into permanent emigration in Romania

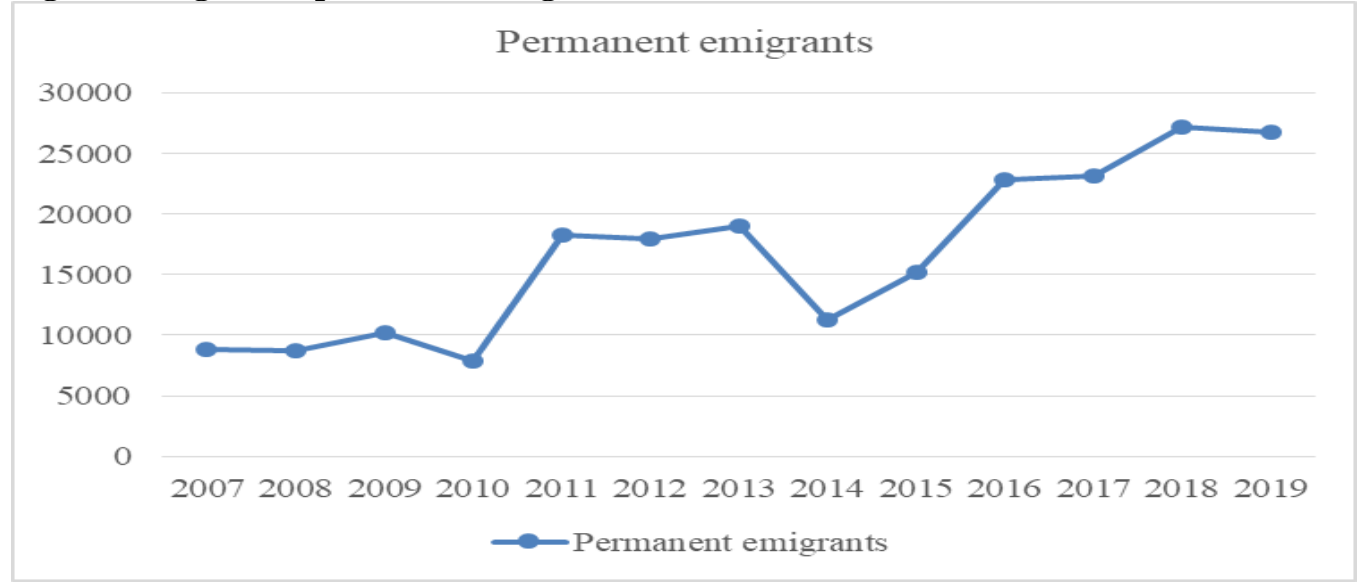

Source: author based on NIS, TEMPO-Online available at 2020

According to that, 2010 registered the lowest number of Romanian permanent emigrants (7906 persons), followed by a three years period when the numbers of Romanian emigrants increased more than double comparative to 2010. Thus, the most recent available data on migration for Romania show that 2016 represented a significant change into Romanian permanent emigrants orientation comparative with the previously years, outlining constantly ascendant trend, and since then the emigration had an increased trends (in 2019 their number being 26775 persons). Similar changes can be notice, also for temporary emigration. The figure below presents its evolution. 
Fig. 2. Changes into temporary emigration in Romania

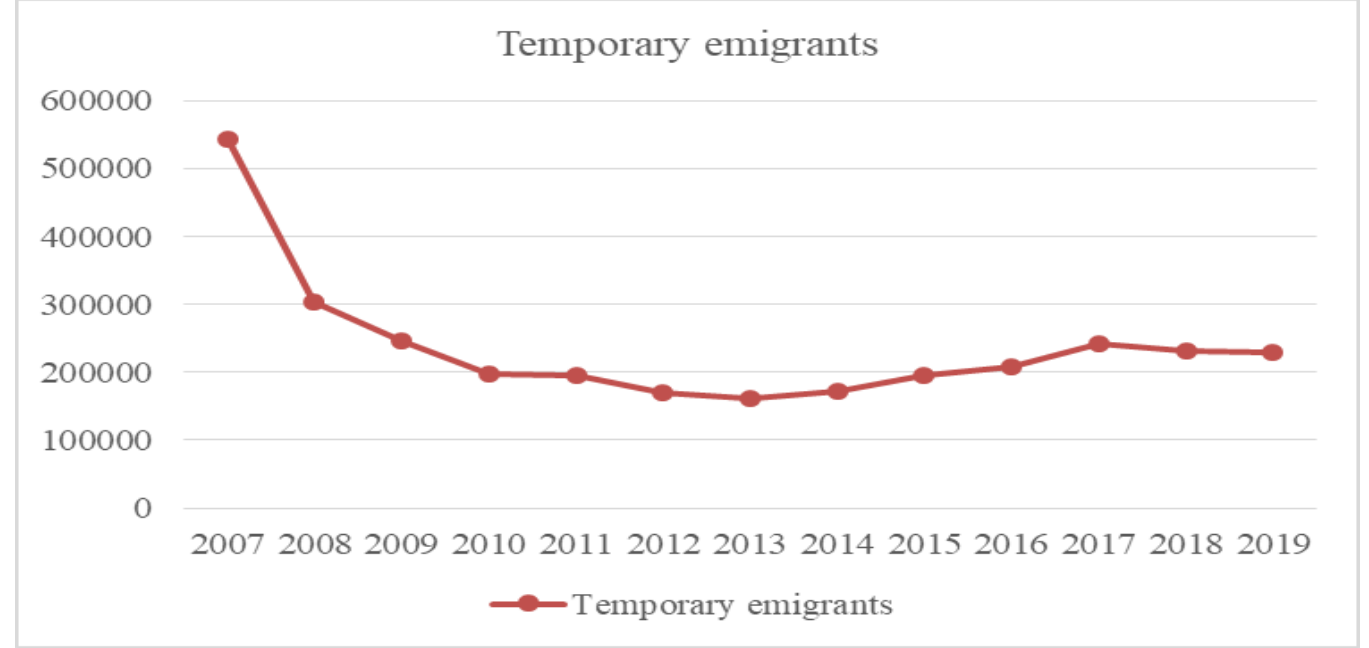

Source: author based on NIS, TEMPO-Online available at 2020

The temporary emigrants' indicator shows that 2007 has been the peak of emigration for Romania (544074 persons). This number continued to decrease in the next years, in 2013 being the lowest level of temporary emigrants (161755 persons), followed by an increasing time. Last data available show both a decrease more than double comparative to 2007 and a double increasing comparative to 2013. This changes are determined especially by the domestic and international changes, such as economic crisis, migration crisis, average monthly net nominal salary and not at least the Covid-19 crisis. In this context, the main countries of destination for emigrants were Spain, Germany and Italy followed by the United State of America and Canada. The figure below depicts the picture according to NIS data.

Fig. 3. Main countries of destination for the emigrants

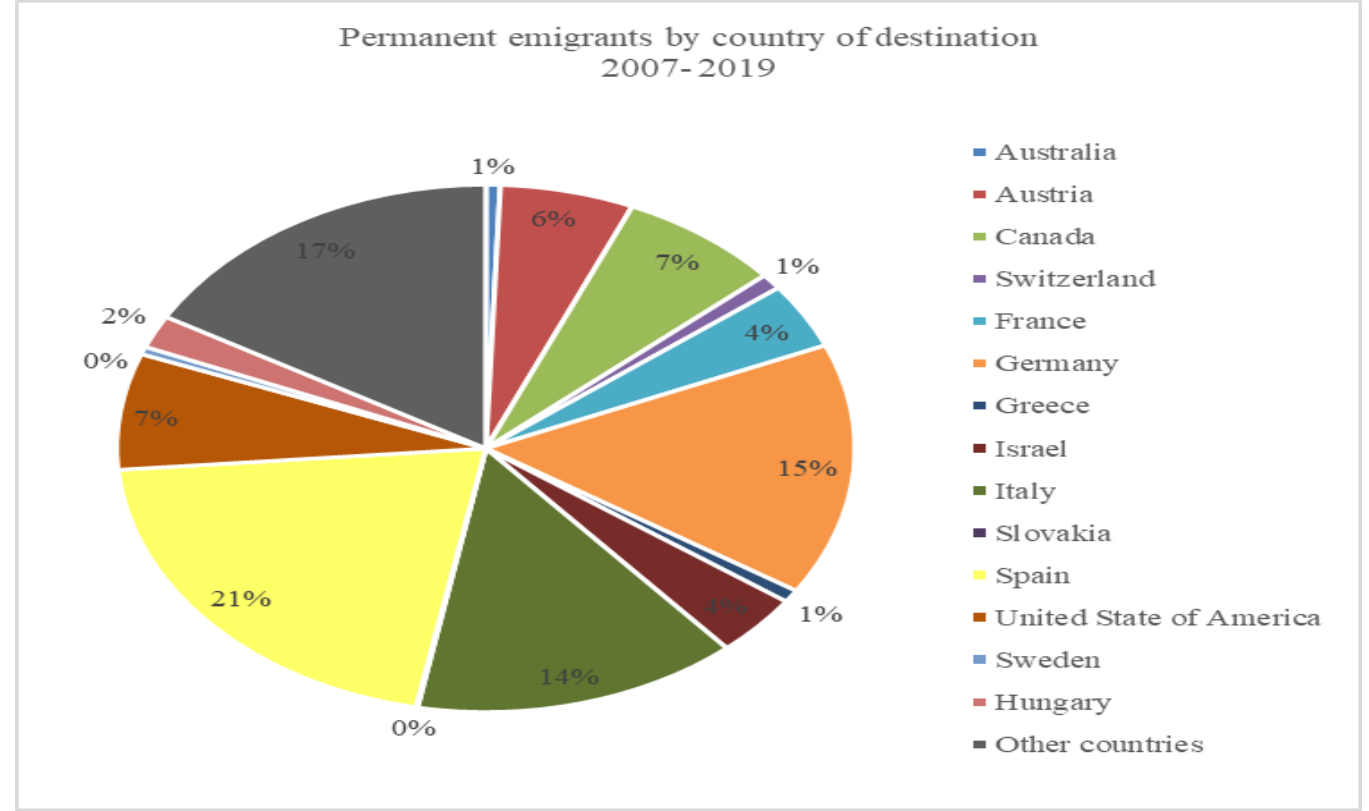

Source: author based on NIS, TEMPO-Online available at 2020 
On the other hand, the immigration situation is reflected by the figures below.

Fig. 4. Immigrants' flows in Romania

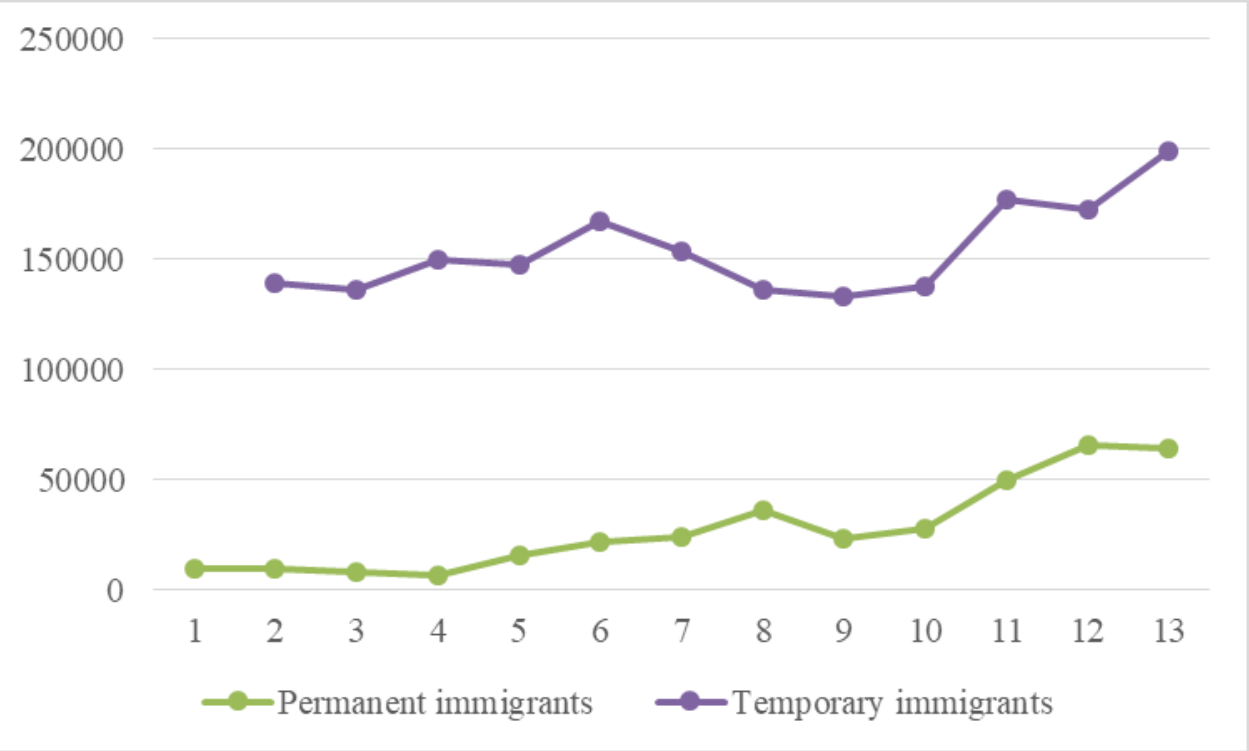

Source: author based on NIS, TEMPO-Online available at 2020

Generally speaking, in the last decade, the average net emigration ratio in Romania has been around 11.05\% .

All these synthetic information presented above for Romania case study are based on national statistics data reported by NIS, and are significantly different from international ones. For example, according to OECD database on Immigrants in OECD Countries (DIOC) "annual legal migration flows from Romania to OECD countries represented 560000 persons in 2007 and 415000 in 2016" (OECD, 2019), comparative to 5529904 in 2007 and 230385 in accordance with national figures.

Another discrepancy between national and international data available in migration indexes is represented by the lack of a statistical indicators in national database managed by NIS for temporary emigrants by country of destination. From Migrant Integration Policy Index (MIPEX), based on its scores 49 on the 100-point MIPEX scale, Romania is included in the equality on paper - halfway unfavourable scenario (country's profile). Additionally, the MIPEX analysis outlines Romania generally appears to adopt similar policies to Bulgaria, Hungary, and Moldova, although policies in those countries are slightly less favourable (MIPEX, 2020).

However, when we look to international data it can be remark that while Romania ranked fifth in total emigrant population, it had the highest emigration rate among the ten main origin countries of emigrants living in OECD countries. The figures from ones international databases (UN DESA, 2019) conclude that the total number of international migrant at the mid-year 2019 for Romania was 462.6 thousand, meaning a stock of 2.4\% of the total population. In accordance with data from United Nations, Department of Economic and Social Affairs (UN DESA), the total number of emigrants from Romania at mid-year 2019 was 3.6 million. 
Therefore, it can be notice a significant different view from national and international data on migration for Romania case. This discrepancy can derived from different methodologies as well as from the fact that NIS use administrative data from Ministry of Home Affairs - Passports General Directorate, General Inspectorate for Immigration and Directorate for Personal Records and Database Administration for available official data on migration and do not combine indicators from various sources into a single index or summary score while for temporary emigrants NIS' methodology states that use the estimation method of migrant flows consists of correlating data from the data sources, such as data provided by national statistical offices of other countries (e.g. Italy and Spain), the "mirror statistics" on international migration (the immigrants from Romania declared by the other Member State representing emigrants on Romanian statistics and, the opposite, the emigrants to Romania declared by other countries representing immigrants for national statistics), data from administrative sources (NIS, 2020).

\section{Conclusions}

The various specialized studies shown that international migration has multiple effects that affect the entire social system. The International Organization for Migration shows that migration has expanded in the last years and the main reason for leaving is the wellbeing of the family at home.

Although this study did not aim to analyse the impact of migration on different sectors, but the reflection of migratory movements in statistics terms in different databases can be seen through the data presented its correlation with other sectors and different national and international economic and political factors.

This study gives a brief portrait on international migration in Romania, and emphasises its lowest presence in various international migration indexes.

Table 6. Several existing indexes on migration policy

\begin{tabular}{|c|c|}
\hline $\begin{array}{l}\text { Migration } \quad \text { indexes } \\
\text { comprehensive approach }\end{array}$ & Countries covered \\
\hline $\begin{array}{l}\text { DEMIG POLICY } \\
\text { (www.migrationdeterminants.eu) }\end{array}$ & $\begin{array}{l}\text { Argentina, Australia, Austria, Belgium, Brazil, Canada, Chile, China, } \\
\text { Czech Republic, Czechoslovakia, Denmark, Finland, France, } \\
\text { Germany, German Democratic Republic, Greece, Hungary, Iceland, } \\
\text { India, Indonesia, Ireland, Israel, Italy, Japan, Korea, Luxembourg, } \\
\text { Mexico, Morocco, Netherlands, New Zealand, Norway, Poland, } \\
\text { Portugal, Russia, Slovakia, Slovenia, South Africa, Spain, Sweden, } \\
\text { Switzerland, Turkey, Ukraine, United Kingdom, United States of } \\
\text { America, Yugoslavia. }\end{array}$ \\
\hline $\begin{array}{l}\text { IMPALA } \\
\text { (https://www.impaladatabase.org/) }\end{array}$ & $\begin{array}{l}\text { Australia, France, Germany, Luxembourg, the Netherlands, Spain, } \\
\text { Switzerland, UK, USA. }\end{array}$ \\
\hline $\begin{array}{l}\text { MIPEX } \\
\text { (https://www.mipex.eu/) }\end{array}$ & $\begin{array}{l}\text { Albania, Australia, Austria, Belgium, Brazil, Bulgaria, Canada, } \\
\text { Chile, China, Croatia, Cyprus, Czechia (Czech Republic), Denmark, } \\
\text { Estonia, Finland, France, Germany, Greece, Hungary, Iceland, India, } \\
\text { Indonesia, Ireland, Israel, Italy, Japan, Korea, Latvia, Lithuania, } \\
\text { Luxembourg, Malta, Mexico, Moldova, Netherlands, New Zealand, } \\
\text { North Macedonia, Norway, Poland, Portugal, Romania, Russia, }\end{array}$ \\
\hline
\end{tabular}




\begin{tabular}{|c|c|}
\hline & $\begin{array}{l}\text { Serbia, Slovakia, Slovenia, Spain, Sweden, Switzerland, Turkey, } \\
\text { Ukraine, United Kingdom, USA. }\end{array}$ \\
\hline $\begin{array}{l}\text { Global Migration Barometer } \\
\text { (https://www.un.org/development/d } \\
\text { esa/pd/sites/www.un.org.developm } \\
\text { ent.desa.pd/files/unpd-cm7-2008- } \\
\text { 11_gmb_execsumeiu.pdf) }\end{array}$ & $\begin{array}{l}\text { Australia, Canada, United States, United Kingdom, Singapore, New } \\
\text { Zealand, Sweden, Hong Kong, Norway, Belgium, Ireland, Portugal, } \\
\text { Switzerland, Spain, Israel, Finland, Germany, France, Netherlands, } \\
\text { Italy, Chile, Austria, Denmark, Costa Rica, Czech Republic, Greece, } \\
\text { Slovakia, Japan, Poland, Lithuania, Mexico, Hungary, Malaysia, } \\
\text { Republic of Korea, Brazil, Qatar, Argentina, Kazakhstan, Peru, } \\
\text { Thailand, Latvia, Russian Federation, Estonia, Turkey, Ukraine, } \\
\text { Romania, United Arab Emirates, Kuwait, Botswana, Ecuador, } \\
\text { China, South Africa, Jordan, Bulgaria, India, Nigeria, Venezuela, } \\
\text { Cote D'Ivoire, Saudi Arabia, Ghana, Iran. }\end{array}$ \\
\hline $\begin{array}{l}\text { ICI } \\
\text { (https://vpham415.github.io/ICI/) }\end{array}$ & US States. \\
\hline $\begin{array}{l}\text { IMPIC } \\
\text { (http://www.impic-project.eu/) }\end{array}$ & $\begin{array}{l}\text { Austria, Australia, Belgium, Canada, Switzerland, Chile, Czech } \\
\text { Republic, Germany, Denmark, EU, Estonia, Spain, Finland, France, } \\
\text { United Kingdom, Greece, Hungary, Ireland, Israel, Iceland, Italy, } \\
\text { Japan, South Korea, Luxembourg, Mexico, Netherlands, Norway, } \\
\text { New Zealand, Poland, Portugal, Sweden, Slovakia, Turkey, United } \\
\text { States of America. }\end{array}$ \\
\hline $\begin{array}{l}\text { MGI } \\
\text { (https://publications.iom.int/es/syst } \\
\text { em/files/pdf/migration_governance } \\
\text { index_2016.pdf) }\end{array}$ & $\begin{array}{l}\text { Bahrain, Bangladesh, Canada, Costa Rica, Germany, Ghana, Italy, } \\
\text { Mexico, Moldova, Morocco, The Philippines, South Africa, South } \\
\text { Korea, Sweden, Turkey }\end{array}$ \\
\hline $\begin{array}{l}\text { Ortega and Peri } \\
\text { (https://mpra.ub.uni- } \\
\text { muenchen.de/19183/1/MPRA_pap } \\
\text { er_19183.pdf) }\end{array}$ & $\begin{array}{l}\text { Algeria, Australia, Austria, Belgium, Bangladesh, Bosnia- } \\
\text { Herzegovina, Brazil, Bulgaria, Cambodia, Canada, Chile, Colombia, } \\
\text { Croatia, Cyprus, Cuba, China, Denmark, Dominican Republic, } \\
\text { Ethiopia, Ecuador, El Salvador, France, Finland, Fiji, Germany, } \\
\text { Guyana, Ghana, Greece, Guatemala, Haiti, Honduras, Hong } \\
\text { Kong, Hungary, Iceland, Ireland, Italy, India, Iran, Iraq, Japan, } \\
\text { Jamaica, Kenya, Luxembourg, Lebanon, Laos, Mexico, Morocco, } \\
\text { Malaysia, Netherlands, Norway, Nigeria, Nicaragua, New } \\
\text { Zealand, Pakistan, Peru, Philippines, Poland, Portugal, Romania, } \\
\text { Russian Federation, Sweden, Switzerland, Slovenia, Spain, Somalia, } \\
\text { South Korea, Sri Lanka, Suriname, South Africa, Thailand, Tunisia, } \\
\text { Turkey, UK, USA, Vietnam, Zaire. }\end{array}$ \\
\hline $\begin{array}{l}\text { DIOC-E } \\
\text { (https://www.oecd.org/els/mig/DIO } \\
\text { C-E-2010-11-methodology.pdf) }\end{array}$ & $\begin{array}{l}100 \text { destination countries and more than } 200 \text { countries of origin, } \\
\text { including Romania }\end{array}$ \\
\hline
\end{tabular}

Source: Author based on EC-JRC, 2018 and databases website

Despite their limitation, all these indexes give a long-standing knowledge for policy-makers and researchers and a journey in time and across countries' perspective on migration issue. However, based on the analysis of different migration databases, it has been reconfirmed the OECD state in accordance with that "it is helpful, if not essential, to compile information directly from destination country data sources, but this is particularly challenging because it requires collecting data based on comparable definitions and concepts from a large number of countries across which emigrants are scattered" (OECD, 2019). There is still a lightening since despite all the problems inherent in the collection of migration data, nowadays the United Nations Population Division and the World Bank 
manage a world origin-destination database for providing a framework for a more precise measurement of global international population movement (IOM, 2019: 5).

\section{ACKNOWLEDGEMENT}

This paper has been elaborated within "Research scholarship Spiru Haret", co-funded by the Executive Unit for Funding Higher Education, Research, Development and Innovation in Romania (UEFISCDI) and National University of Political Studies and Public Administration within the project PN-III-P1-1.1-BSH-2-2016-0005

\section{References}

1. Beine, Michel et al. (2016). Comparing Immigration Policies: An Overview from the IMPALA Database, International Migration Review, 50:4, 827-863. https://doi.org/10.1111\%2Fimre.12169

2. DEMIG., (2015a). DEMIG C2C, version 1.2, Limited Online Edition. Oxford: International Migration Institute, University of Oxford. www.migrationinstitute.org

3. DEMIG., (2015b). DEMIG TOTAL, version 1.5. Oxford: International Migration Institute, University of Oxford. www.imi-n.org

4. DEMIG., (2015c). DEMIG VISA, version 1.4, Full Edition. Oxford: International Migration Institute, University of Oxford.

5. Dogaru (Cruceanu), T.-C., 2019. The comparative method for policy studies: the thorny aspects, Holistica. vol 10, issue 1: 56-67. https://doi.org/10.2478/hjbpa-2019-0005

6. European Commission - Joint Research Centre., 2018. Migration Policy Index. European Union: EC.

7. Gest, Justin et al. (2014). Measuring and Comparing Immigration, Asylum and Naturalization Policies Across Countries: Challenges and Solutions, Global Policy, 5:3, 261-274. https://doi.org/10.1111/1758-5899.12132

8. Hatton, Timothy J. (2009). The Rise and Fall of Asylum: What Happened and Why?, The Economic Journal, 119:535, F183-F213. https://doi.org/10.1111/j.1468-0297.2008.02228.x

9. International Organization for Migration (IOM)., (2018). Global migration indicators. Germany: Global Migration Data Analysis Centre (GMDAC).

10. International Organization for Migration (IOM)., 2019. World Migration Report 2020. International Organization for Migration, retrived from https://publications.iom.int/system/files/pdf /wmr_2020.pdf

11. Jupp, V. (2006). The Sage Dictionary of Social Research Methods. UK: Sage publications

12. Lupu, D., Maha, L. G., \& Viorică, E. D. (2020). COVID-19 Incidence in Europe: Drivers and Government Interventions. Transylvanian Review of Administrative Sciences, 16(SI), 80-93. http://dx.doi.org/10.24193/tras.SI2020.5

13. Mayda, AM, Patel, K. (2004). Appendix: OECD Countries Migration Policy Changes, in Mayda, AM. International Migration: A Panel Data Analysis of Economic and Non-Economic Determinants.

14. Ruhs, M. (2011). Openness, Skills and Rights: An empirical analysis of labour immigration programmes in 46 high- andmiddle-income countries, COMPAS Working Paper Series. Oxford: COMPAS. 15. MIPEX (2020). Solano, Giacomo \& Huddleston, Thomas. Migrant Integration Policy Index. Barcelona: Barcelona Center for International Affair.

16. Economist Intelligence Unit. (2008). Global Migration Barometer. Retrieved from https://www.un.org/development/desa/pd/sites/www.un.org.development.desa.pd/files/unpd-cm7-200811_gmb_execsumeiu.pdf

17. Romanian National Institute of Statistics. (2020). TEMPO-Online Retrieved from http://statistici.insse.ro:8077/tempo-online/\#/pages/tables/insse-table

18. OECD. (2019). Talent Abroad: A Review of Romanian Emigrants, Paris: OECD Publishing. https://doi.org/10.1080/14683857.2019.1681664 
19. United Nations, Department of Economic and Social Affairs (UN DESA). (2019). International migrant stock 2019: Country Profiles Retrieved from https://www.un.org/en/development/desa/population/migration/data/estimates2/countryprofiles.as

20. World Bank. (2018). Romania. Systematic Country Diagnostic. Retrieved from http://documents1.worldbank.org/curated/en/210481530907970911/pdf/128064-SCD-PUBLIC-P160439-

RomaniaSCDBackgroundNoteMigration.pdf

21. https://www.oecd.org/els/mig/DIOC-E-2010-11-methodology.pdf

22. https://mpra.ub.uni-muenchen.de/19183/1/MPRA_paper_19183.pdf

23. https://publications.iom.int/es/system/files/pdf/migration_governance_index_2016.pdf

24. http://www.impic-project.eu/

25. https://vpham415.github.io/ICI/

26. https://www.un.org/development/desa/pd/sites/www.un.org.development.desa.pd/files/unpd-cm72008-11_gmb_execsumeiu.pdf Creative Commons Attribution - Non Commercial - No Derivatives 4.0 International License. 